\title{
Nitrogen assimilation characteristics of polar seaweeds from differing nutrient environments
}

\author{
Rebecca E. Korb ${ }^{1, *}$, Valrie A. Gerard ${ }^{2}$ \\ ${ }^{1}$ Wrigley Institute of Environmental Studies, University of Southern California, PO Box 5069, Avalon, California, \\ 90704-5069, USA \\ ${ }^{2}$ Marine Sciences Research Centre, State University of New York, Stony Brook, New York 11794-5000, USA
}

\begin{abstract}
Nitrogen uptake and assimilation strategies were compared in polar macroalgae from differing dissolved inorganic nitrogen (DIN) regimes. The antarctic endemic, Himantothallus grandifolius, experiences high nitrate concentrations year-round and occasionally high, but variable, ammonium levels. The arctic endemic, Laminaria solidungula, is exposed to seasonal fluctuations in DIN, with Nlimitation occurring during the summer. Both species demonstrated saturation kinetics for nitrate and ammonium uptake. L. solidungula showed 'storage-specialist' characteristics of nitrate uptake, with high $V_{\max }$ allowing this species to take advantage of seasonally elevated nitrate concentrations. $H$. grandifolius had a high $V_{\max }$ for ammonium, allowing the alga to utilise pulses of this nutrient. In the presence of both DIN forms, nitrate uptake was significantly reduced in both species. Furthermore, $H$. grandifolius and $L$. solidungula demonstrated significantly reduced uptake and assimilation of nitrate during short-term and prolonged periods of darkness, while ammonium uptake and assimilation were relatively unaffected by light. Although preferential uptake of ammonium, particularly in the dark, allows both species to conserve energy in their cold, low-light environments, the antarctic species, which does not have the additional problem of $\mathrm{N}$-limitation, showed stronger energy-conserving traits. Nitrogen assimilation characteristics of the arctic species appeared to balance energy conservation with the need to minimise $\mathrm{N}$-limitation in an environment that alternates between low light and low $\mathrm{N}$ availability.
\end{abstract}

KEY WORDS: Himantothallus grandifolius - Laminaria solidungula Nitrogen assimilation $\cdot$ Algae Antarctic $\cdot$ Arctic

\section{INTRODUCTION}

High-latitude marine environments are characterised by low and almost constant water temperatures (Drew \& Hastings 1992, Sellman et al. 1992), and polar endemic algae exhibit adaptations which allow them to maintain relatively high rates of primary production at near-freezing temperature (Wiencke \& tom Dieck 1989, Bischoff \& Wiencke 1993, Dunton \& Dayton 1995 Newkirk 1997, V.A.G. unpubl. data). Light and nutrient availability, in contrast, are highly variable in polar marine environments, and are the most important factors influencing seasonal variation in algal production.

•E-mail:korb@wrigley.usc.edu
Growth of Himantothallus grandifolius (A. \& E. S. Geppl Moe \& Silva, a brown macroalga endemic to the Antarctic, is largely restricted to the summer months when sea-ice breaks up and underwater light levels are high (Drew \& Hastings 1992). Growth patterns of the arctic kelp Laminaria solidungula J. Ag. are very different from those of its antarctic counterpart; stored carbon is used to produce new tissue during the dark winter months, while growth virtually stops during the ice-free summer (Dunton \& Schell 1986, Dunton 1990). Differences in seasonal growth patterns of these 2 species are primarily a response to the availability of nutrients. In the Southern Ocean, dissolved inorganic nitrogen (DIN) levels remain high throughout the year; growth of $H$. grandifolius is rarely, if ever, N-limited and follows the seasonal light pattern (Drew \& Hastings 
1992). In arctic seas, DIN levels are depleted during the summer by production of microalgal biomass, but increase over the winter months. Growth of $L$. solidungula is strongly $\mathrm{N}$-limited during the summer and, therefore, follows the seasonal pattern of DIN availability (Chapman \& Lindley 1980, Henley \& Dunton 1995).

DIN uptake and assimilation characteristics of temperate seaweeds have been shown to vary among populations and species in ways that optimise survival and growth under local nutrient supply conditions (Davison \& Stewart 1983, Espinoza \& Chapman 1983, Wheeler \& Weidner 1983, Davison et al. 1984, Kopczak 1994). Arctic and antarctic macroalgae, which occur in environments with similar low temperature/low irradiance conditions but very different $\mathrm{N}$-supply regimes, may also exhibit adaptive differences in nutritional strategies. Thus, Laminaria solidungula has been shown to accumulate large internal reserves of nitrogenous compounds which can support growth for months during periods of low external $\mathrm{N}$-supply, while internal $\mathrm{N}$-reserves in Himantothallus grandifolius are minimal (Korb \& Gerard 2000, in this issue). The present study compared DIN uptake and assimilation in L. solidungula and $H$. grandifolius. Both of these species are major biomass components and primary producers in their respective polar, shallow marine ecosystems (Dunton 1984, Amsler et al. 1995). Although H. grandifolius was recently reclassified from the order Laminariales to the closely related Desmarestiales (Tan \& Druehl 1996), its morphology, physiology, and life history are similar to $L$. solidungula (Moe \& Silva 1981).

\section{MATERIALS AND METHODS}

Sporophytes of Himantothallus grandifolius, 10 to $30 \mathrm{~cm}$ in blade length, were collected using SCUBA at 15 to $20 \mathrm{~m}$ depths from a site located near Palmer Station $\left(64^{\circ} 46^{\prime} \mathrm{S}, 64^{\circ} 04^{\prime} \mathrm{W}\right)$ on Anvers Island, Antarctic Peninsula, during March and April 1997. Sporophytes of Laminaria solidungula, approximately $15 \mathrm{~cm}$ in length, were collected from the Canadian High Arctic at Resolute Bay, Cornwallis Island $\left(74^{\circ} 30^{\prime} \mathrm{N}, 95^{\circ} \mathrm{W}\right)$ during May 1997. Plants were maintained in 81 batch cultures with 5 plants per tub, and $0^{\circ} \mathrm{C}$ aerated seawater enriched with $240 \mu \mathrm{M} \mathrm{NO}_{3}{ }^{-}$and $16 \mu \mathrm{M} \mathrm{PO}_{4}{ }^{-3}$. Seawater was changed twice weekly and nutrients added at this time. Irradiance was provided by cool white fluorescent lamps at a photon flux density (PFD) of $50 \mu \mathrm{mol} \mathrm{m} \mathrm{m}^{-2} \mathrm{~s}^{-1}$, on a $16 \mathrm{~h}$ light: $8 \mathrm{~h}$ dark cycle. Plants were held under these constant conditions for at least 4 wk prior to experimental use.

Nitrate and ammonium uptake. Plants were placed in $2 \mathrm{l}$ of nitrate-free seawater for approximately $30 \mathrm{~min}$ to remove excess $\mathrm{NO}_{3}{ }^{-}$from intercellular tissue space
(Gerard 1982). All measurements were performed at $0^{\circ} \mathrm{C}$. Standard solutions of either $10 \mathrm{mM}$ sodium nitrate or ammonium chloride were added to $4.8 \mathrm{l}$ of seawater to give initial concentrations between 0 and $120 \mu \mathrm{M} \mathrm{NO}_{3}{ }^{-}$or 0 to $25 \mu \mathrm{M} \mathrm{NH}_{4}{ }^{+}$. The water was mixed well, and triplicate $1.0 \mathrm{ml}$ samples were immediately removed for $\mathrm{NO}_{3}{ }^{-}$analysis. For $\mathrm{NH}_{4}{ }^{+}, 12.5 \mathrm{ml}$ of seawater was removed and added to $0.5 \mathrm{ml}$ of phenol to fix samples. Aliquots $(800 \mathrm{ml})$ of the seawater $/ \mathrm{N}$ mix were added to 5 shallow, white plastic trays (1.5 l total volume). Water motion was generated by aeration, and irradiance was maintained at $50 \mu \mathrm{mol} \mathrm{m} \mathrm{m}^{-2}$ $\mathrm{s}^{-1}$. For measurements of uptake in the light, individual plants were blotted to remove excess water, then placed in one of the trays for 5 to $7 \mathrm{~h}$, after which plants were removed, the water was mixed well, and a second set of triplicate samples was removed from each tray. $\mathrm{NO}_{3}^{-}$uptake in the presence of $\mathrm{NH}_{4}{ }^{+}$was examined using the previously described experimental procedure in seawater containing both $5 \mu \mathrm{M} \mathrm{NO}_{3}{ }^{-}$ and $5 \mu \mathrm{M} \mathrm{NH}_{4}{ }^{+}$. Short-term, dark uptake rates were measured over $7 \mathrm{~h}$ in the presence of either $\mathrm{NO}_{3}{ }^{-}$or $\mathrm{NH}_{4}{ }^{+}$at saturating or close to saturating $\mathrm{N}$-concentrations, as determined in light experiments, to give maximum rates of uptake in the dark. Lights in the incubator were turned off, and the trays covered with black plastic bags. At the end of each experiment, blotted wet weight was measured for each plant, and blade area was determined by paper tracings. The change in $\mathrm{NO}_{3}{ }^{-}$concentration over time was determined using the method of A. Gao (pers. comm.) modified from Jones (1984) as described in Korb \& Gerard (2000). Changes in $\mathrm{NH}_{4}{ }^{+}$concentrations over time were determined using the alternative ammonium assay described by Parsons et al. (1984).

Enzyme activities. Crude enzyme extracts were prepared using a modified version of the method described by Hurd et al. (1995). Discs (2.27 $\mathrm{cm}^{2}$ ) were cut from mature blade tissue with a cork borer, frozen immediately in liquid nitrogen, and stored at $-80^{\circ} \mathrm{C}$ until required for use. Fresh algal thalli could be frozen for several weeks without loss of enzyme activity (data not shown). Frozen tissue was ground to a fine powder under liquid nitrogen with a mortar and pestle. For each $0.1 \mathrm{~g}$ wet wt of tissue (approximately $1 \mathrm{disc}$ ), $2 \mathrm{ml}$ of ice-cold extraction buffer containing $200 \mathrm{mM}$ phosphate buffer ( $\mathrm{pH} 7.9$ ), $5 \mathrm{mM}$ EDTA, $20 \mathrm{mM}$ dithiothreitol (DTT), $7.5 \mu \mathrm{M}$ PVP and $1 \%(\mathrm{v} / \mathrm{v})$ Triton X-100 were added; the sample was reground to homogeneity and centrifuged for $5 \mathrm{~min}$ at $4^{\circ} \mathrm{C}(10000 \times g)$. Extracts were kept on ice and assayed within $30 \mathrm{~min}$.

Nitrate reductase (NR) activity in the supernatant of the crude extracts was determined in an assay mixture containing $0.2 \mathrm{mM} \mathrm{NADH}, 10 \mathrm{mM} \mathrm{KNO}_{3}$, and $200 \mathrm{mM}$ phosphate buffer ( $\mathrm{pH}$ 7.9). Reactions were started by 
adding $0.4 \mathrm{ml}$ crude enzyme extract to $1.6 \mathrm{ml}$ assay mix; $1 \mathrm{ml}$ was removed immediately and added to $1 \mathrm{ml}$ of $550 \mathrm{mM}$ zinc acetate. The remaining $1 \mathrm{ml}$ was incubated for $30 \mathrm{~min}$ at $10^{\circ} \mathrm{C}$ and the reaction stopped by the addition of $1 \mathrm{ml}$ zinc acetate. Samples were centrifuged for $5 \mathrm{~min}(10000 \times \mathrm{g})$. Of the resulting supernatant, $0.5 \mathrm{ml}$ was removed, added to $20 \mu \mathrm{l}$ of $825 \mu \mathrm{M}$ phenazine methylsulphate, and allowed to stand for 20 min. $\mathrm{NO}_{2}{ }^{-}$was measured spectrophotometrically at $540 \mathrm{~nm}$ (Parsons et al. 1984) after the addition of $0.5 \mathrm{ml}$ each of $58 \mathrm{mM}$ sulfanilamide (in $1 \mathrm{M} \mathrm{HCl}$ ) and $3.86 \mathrm{mM} \mathrm{N}$-1-napthylethylenediamine.

Curves of NR activity versus substrate concentration were generated by measuring NR activity at concentrations of $\mathrm{KNO}_{3}{ }^{-}$ranging from 0 to $20 \mathrm{mM}$. Laminaria

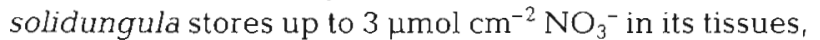
which masks actual NR activity in the presence of low external $\mathrm{NO}_{3}{ }^{-}$concentrations. Therefore, this alga was maintained in nitrate-free seawater for $12 \mathrm{wk}$ prior to experimental use. Diel NR activity of Himantothallus grandifolius was measured every $2 \mathrm{~h}$ over a $24 \mathrm{~h}$ period.

For glutamine synthetase (GS) activity, enzyme extracts were prepared as for NR with the following exceptions: for each $0.1 \mathrm{~g}$ fresh wt of tissue, $1 \mathrm{ml}$ of ice-cold extraction buffer containing $200 \mathrm{mM}$ HEPES buffer ( $\mathrm{pH} 7.9$ ), $50 \mathrm{mM} \mathrm{MgCl} 2,5 \mathrm{mM}$ EDTA, $20 \mathrm{mM}$ DTT, $7.5 \mu \mathrm{M}$ PVP and $1 \%(\mathrm{v} / \mathrm{v})$ Triton X-100 was added. GS activity was measured following the method of Rees et al. (1995) in an assay mix containing $50 \mathrm{\mu l}$ crude enzyme extract, $8 \mathrm{mM}$ ATP, $100 \mathrm{mM}$ glutamate, and $50 \mathrm{mM}$ ammonium chloride added to basic HEPES buffer (minus PVP and Triton-X) to give a final volume of $750 \mu$ l. Reactions were started by addition of ATP. Blanks consisted of the same additions minus glutamate. Samples were incubated for $15 \mathrm{~min}$ at $30^{\circ} \mathrm{C}$, the reaction stopped by adding $0.25 \mathrm{ml} 1 \mathrm{M} \mathrm{H}_{2} \mathrm{SO}_{4}$, and the samples centrifuged for $1 \mathrm{~min}(16000 \times g)$. Of the resulting supernatant, $25 \mu \mathrm{l}$ was added to $975 \mu \mathrm{l}$ of distilled water, and inorganic phosphate was measured as in Rees et al. (1995).

Effects of prolonged darkness on $\mathbf{N}$-assimilation. To determine which, if any, nitrogen source is taken up during periods of prolonged darkness and the effect on enzyme activity, sporophytes of Himantothallus grandifolius and Laminaria solidungula were grown in the dark as $8 \mathrm{l}$ batch cultures for $1 \mathrm{mo}$. All other culture conditions were as described previously. After 1 mo in darkness, plants were placed under a PFD of $50 \mu \mathrm{mol}$ photons $\mathrm{m}^{-2} \mathrm{~s}^{-1}$, on a $16 \mathrm{~h}$ light: $8 \mathrm{~h}$ dark cycle. At 0,2 , and $7 \mathrm{~d}$ in the light, NR, GS, and $\mathrm{NO}_{3}{ }^{-} / \mathrm{NH}_{4}{ }^{+}$uptake rates were measured. Discs of mature blade tissue were cut for NR and GS, frozen immediately in liquid nitrogen, and stored at $-80^{\circ} \mathrm{C}$ until analysis. For uptake experiments, whole plants were incubated in either
$5 \mu \mathrm{M} \mathrm{NO}_{3}{ }^{-}$or $5 \mu \mathrm{M} \mathrm{NH}_{4}{ }^{+}$with a PFD of $50 \mu \mathrm{mol}$ photons $\mathrm{m}^{-2} \mathrm{~s}^{-1}$.

Effect of nitrogen limitation on $\mathrm{N}$-assimilation. To examine the effect of nitrogen limitation on NR and $\mathrm{NO}_{3}{ }^{-}$uptake, Himantothallus grandifolius was grown as $8 \mathrm{l}$ batch cultures in nitrate-free seawater for 1 mo and Laminaria solidungula for 3 mo (at which point internal $\mathrm{NO}_{3}^{-}$pools had been depleted). All other culture conditions were as described previously. After 1 or 3 mo without $\mathrm{NO}_{3}{ }^{-}$, samples were taken for NR activity, frozen immediately in liquid nitrogen, and stored at $-80^{\circ} \mathrm{C} . \mathrm{NO}_{3}{ }^{-}$uptake experiments were performed on whole plants of $H$. grandifolius with $800 \mathrm{ml}$ of seawater containing $30 \mu \mathrm{M} \mathrm{NO}_{3}{ }^{-}$. Due to the time constraints involved in producing $L$. solidungula plants with depleted internal $\mathrm{NO}_{3}{ }^{-}$pools, it was not possible to perform $\mathrm{NO}_{3}{ }^{-}$uptake experiments.

Statistical analyses. Maximum uptake rates $\left(V_{\operatorname{miax}}\right)$ and half saturation constants $\left(K_{\mathrm{m}}\right)$ for $\mathrm{N}$-uptake and NR were calculated from non-linear regressions (least squares analysis) using the curve fitting package Semi-Newton (SYSTAT NLIN procedure; see Berges et al. 1994). The $\mathrm{NO}_{3}{ }^{-}$and $\mathrm{NH}_{4}{ }^{+}$uptake data of Laminaria solidungula did not fit a hyperbolic curve when data points from high $\mathrm{N}$ concentrations were included. To aid comparisons with Himantothallus grandifolius, these points were removed and $V_{\max }$ and $K_{\mathrm{m}}$ calculated using SYSTAT. Statistical analyses were made using either a 1-or 2-way ANOVA (Fully Factorial MGLH, SYSTAT) followed by multiple comparisons testing using the Tukey-Kramer HSD-test (testing for significance at $\mathrm{p}<0.05$ ) or a Student's $t$-test when only 1 factor was involved.

\section{RESULTS}

\section{$\mathrm{N}$-uptake and -assimilation in the light}

Uptake measurements showed differences in characteristics between antarctic Himantothallus grandifolius and arctic Laminaria solidungula in relation to differences in ambient DIN availability. The arctic plants had a higher $V_{\max }$ but a lower affinity (higher $K_{m}$ ) for $\mathrm{NO}_{3}{ }^{-}$than the antarctic plants (Fig. 1, Table 1). In contrast, $H$. grandifolius had a higher $V_{\max }$ but a lower affinity for $\mathrm{NH}_{4}{ }^{+}$than $L$. solidungula. Similar $V_{\max } / K_{\mathrm{m}}$ ratios for both forms of DIN, however, indicated similar uptake efficiencies for the 2 species. The arctic species was more sensitive than the antarctic species to high concentrations of $\mathrm{NO}_{3}{ }^{-}$or $\mathrm{NH}_{4}{ }^{+}$. $\mathrm{NO}_{3}{ }^{-}$ uptake by $L$. solidungula was $70 \%$ lower at $120 \mu \mathrm{M}$ than at $60 \mu \mathrm{M}$, and $\mathrm{NH}_{4}{ }^{+}$uptake was inhibited at $17 \mu \mathrm{M}$. H. grandifolius, in contrast, showed no deleterious effects of high substrate concentrations. 


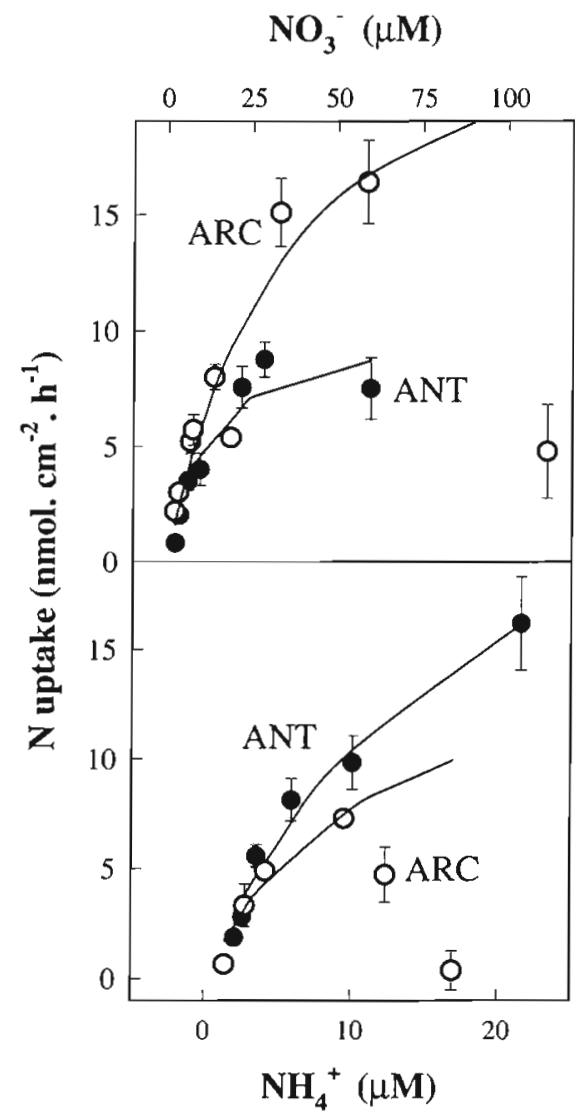

Fig. 1. $\mathrm{NO}_{3}{ }^{-}$and $\mathrm{NH}_{4}{ }^{+}$uptake by antarctic Himantothallus grandifolius (ANT, filled symbols) and arctic Laminaria solidungula (ARC, open symbols). Results represent the mean $( \pm 1 \mathrm{SE})$ of 5 or 6 individual plants. Lines represent non-linear transformations using SYSTAT; data points for L. solidungula from the highest concentrations were not included. Correlation coefficients for $\mathrm{NO}_{3}{ }^{-}$and $\mathrm{NH}_{4}{ }^{+}$were $\mathrm{r}^{2}=0.90$ and 0.93 , respectively, for $H$. grandifolius, and $r^{2}=0.93$ and 0.93 for $L$. solidungula

$\mathrm{NH}_{4}{ }^{+}$and $\mathrm{NO}_{3}{ }^{-}$were taken up simultaneously by antarctic and arctic plants when both forms were present (Fig. 2). $\mathrm{NO}_{3}{ }^{-}$uptake was 65 to $70 \%$ lower than $\mathrm{NH}_{4}^{+}$uptake in Himantothallus grandifolius, regardless of whether $\mathrm{N}$-forms were supplied singly or together. The presence of the $\mathrm{N}$-forms together lowered uptake of both $\mathrm{NO}_{3}^{-}$and $\mathrm{NH}_{4}^{+}$. In Laminaria solidungula, the presence of both $\mathrm{N}$-forms reduced $\mathrm{NO}_{3}{ }^{-}$uptake by $45 \%$, but had no effect on $\mathrm{NH}_{4}{ }^{+}$ uptake. Differences between uptake rates measured for each $\mathrm{N}$-form individually and rates measured in the presence of both $\mathrm{N}$-forms were statistically significant (ANOVA, $F=24.7$ for $H$. grandifolius, and $F=7.7$ for $L$. solidungula, $\mathrm{p}<0.01$ ).

$\mathrm{NR}$ activity measured at varying $\mathrm{NO}_{3}{ }^{-}$concentrations followed Michaelis-Menton saturation kinetics

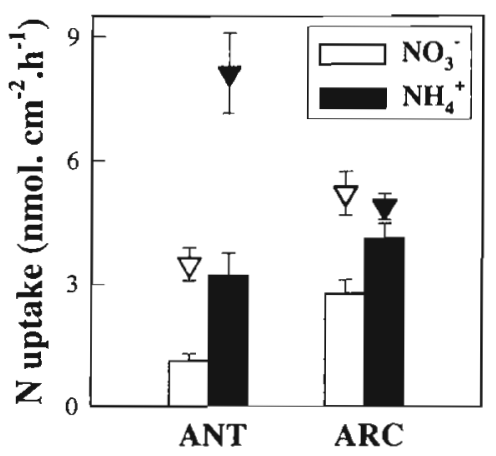

Fig. 2. Uptake rates of $\mathrm{NO}_{3}{ }^{-}$and $\mathrm{NH}_{4}{ }^{+}$by antarctic Himantothallus grandifolius (ANT) and arctic Laminaria solidungula (ARC) when only 1 form was present (symbols) or when both forms were present together (bars). Open bars represent $\mathrm{NO}_{3}{ }^{-}$ uptake and filled bars $\mathrm{NH}_{4}{ }^{+}$uptake (mean $\pm 1 \mathrm{SE}, \mathrm{n}=5$ or 6 ). Initial concentrations were $5 \mu \mathrm{M}$ in all cases

Table 1. Mean $V_{\max }$ and $K_{\mathrm{m}}$ values $\left\{ \pm 1 \mathrm{SE}\right.$ ) of $\mathrm{NO}_{3}{ }^{-}$and $\mathrm{NH}_{4}{ }^{+}$ utake by whole plants of Himantothallus grandifolius and Laminaria solidungula ( $\mathrm{n}=5$ or 6 individual plants at each concentration)

\begin{tabular}{|lcc|}
\hline & H. grandifolius & L. solidungula \\
\hline $\mathrm{NO}_{3}{ }^{-}$ & & \\
$V_{\max }\left(\mathrm{nmol} \mathrm{cm}{ }^{-2} \mathrm{~h}^{-1}\right)$ & $10.6 \pm 1.1$ & $26.7 \pm 4.3$ \\
$K_{\mathrm{m}}(\mu \mathrm{M})$ & $12.8 \pm 3.5$ & $35.0 \pm 10.6$ \\
$V_{\text {raax }} / K_{\mathrm{m}}$ & 0.83 & 0.76 \\
$\mathrm{NH}_{4}{ }^{+}$ & & \\
$V_{\max }\left(\mathrm{nmol} \mathrm{cm}{ }^{-2} \mathrm{~h}^{-1}\right)$ & $31.4 \pm 6.7$ & $17.4 \pm 6.4$ \\
$K_{\mathrm{m}}(\mu \mathrm{M})$ & $20.4 \pm 7.4$ & $12.7 \pm 7.0$ \\
$V_{\max } / K_{\mathrm{m}}$ & 1.54 & 1.37 \\
\hline
\end{tabular}

for both Himantothallus grandifolius and Laminaria solidungula (Fig. 3). Similar to $V_{\max }$ of $\mathrm{NO}_{3}^{-}$uptake, $V_{\max }$ of NR activity was higher in the arctic than in the antarctic species (Table 2); however, NR activity of arctic plants showed a higher affinity for $\mathrm{NO}_{3}{ }^{-}$and a higher $V_{\text {max }} / K_{\mathrm{m}}$ ratio, indicating more efficient enzyme activity than in antarctic plants.

\section{Effects of darkness and $\mathrm{NO}_{3}{ }^{-}$availability on $\mathrm{N}$-uptake and -assimilation}

Comparison of $\mathrm{N}$-uptake under short-term exposure to light and dark showed that effects depended on the form of nitrogen, i.e. there was a significant interactive effect of light and N-form on uptake rate for both Himantothallus grandifolius and Laminaria solidingula (2-way ANOVA, $F=23.3$ and 6.7 , respectively, $\mathrm{p}<0.05$ ). Both species were unable to take up significant amounts of 


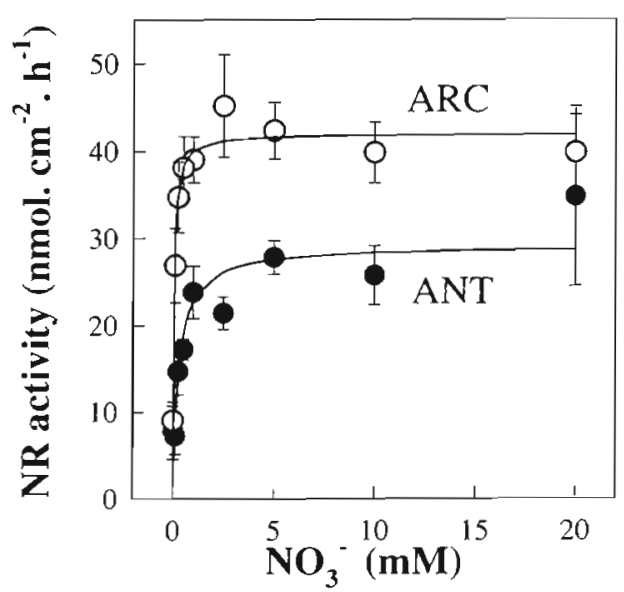

Fig. 3. Nitrate reductase (NR) activity at varying substrate concentrations in antarctic Himantothallus grandifolius (ANT, filled symbols) and arctic Laminaria solidungula (ARC, open symbols). Each point represents the mean ( $\pm 1 \mathrm{SE}$ ) of 3 or 4 individual plants. Lines represent non-linear transformations using SYSTAT $\mathrm{r}^{2}=0.88$ for $H$. grandifolius and $\mathrm{r}^{2}=0.95$ for L. solidungula

Table 2. Mean ( $\pm 1 \mathrm{SE}) V_{\max }$ and $K_{\mathrm{m}}$ values for nitrate reductase activity versus substrate concentration for Himantothallus grandifolius and Laminaria solidungula $(\mathrm{n}=3$ or 4 individual plants)

\begin{tabular}{|ccc|}
\hline & H. grandifolius & L. solidungula \\
\hline$V_{\max }\left(\mathrm{nmol} \mathrm{cm} \mathrm{cm}^{-2} \mathrm{~h}^{-1}\right)$ & $29.13 \pm 2.41$ & $42.03 \pm 1.81$ \\
$K_{\mathrm{m}}(\mathrm{mM})$ & $0.28 \pm 0.12$ & $0.05 \pm 0.02$ \\
$V_{\max } / K_{\mathrm{m}}$ & 0.10 & 0.84 \\
\hline
\end{tabular}

$\mathrm{NO}_{3}{ }^{-}$in the dark, and the antarctic plants actually appeared to release a small amount (Table 3). Dark uptake rates were significantly higher for $\mathrm{NH}_{4}{ }^{+}$than for $\mathrm{NO}_{3}{ }^{-}$for both species (Tukey's HSD-test, $\mathrm{p}<0.05$ ), and although $\mathrm{NH}_{4}{ }^{+}$uptake by both species was 20 to $26 \%$ lower in the dark than in the light, the effects of light on $\mathrm{NH}_{4}{ }^{+}$uptake were not statistically significant.

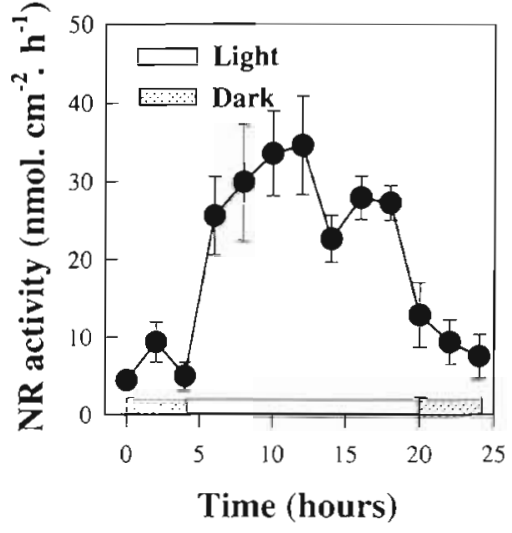

Fig. 4. Diel activity of nitrate reductase (NR) in antarctic Himantothallus grandifolius. Plants were grown on a $16 \mathrm{~h}$ light: $8 \mathrm{~h}$ dark cycle in a photon flux density of $50 \mu \mathrm{mol} \mathrm{m}^{-2} \mathrm{~s}^{-1}$ at $0^{\circ} \mathrm{C}$ with $240 \mu \mathrm{M} \mathrm{NO}_{3}{ }^{-}$Each point represents the mean $( \pm 1 \mathrm{SE})$ of 3 individual plants

Long-term exposure to darkness had effects on $\mathrm{N}$-uptake similar to effects of short-term exposure. After 1 mo darkness, both Himantothallus grandifolius and Laminaria solidungula exhibited significantly lower rates of $\mathrm{NO}_{3}^{-}$uptake compared to control plants (Table 4, ANOVA, $F=44.5$ and 32.3, respectively, $\mathrm{p}<0.01$ ). The antarctic species was still unable to take up $\mathrm{NO}_{3}{ }^{-} 2 \mathrm{~d}$ after its return to a diel light cycle, but both species showed full recovery of $V_{\max }$ after a week. In contrast to $\mathrm{NO}_{3}{ }^{-}$uptake, both species took up significant amounts of $\mathrm{NH}_{4}{ }^{+}$immediately following 1 mo in darkness. Initial rates of $\mathrm{NH}_{4}{ }^{+}$uptake in $\mathrm{H}$. grandifolius were only $20 \%$ of rates by control plants, while uptake rates of dark-treated $L$. solidungula were $75 \%$ of control plants.

NR activity in Himantothallus grandifolius declined during short-term exposure to darkness almost as markedly as $\mathrm{NO}_{3}{ }^{-}$uptake, resulting in a diel pattern (Fig. 4) similar to those found in other algal species (Davison \& Stewart 1984, Gao et al. 1992, Lopes et al. 1997, Vegara et al. 1998). NR activity rose rapidly within $2 \mathrm{~h}$ of the start of the light cycle, peak activity (approximately 4 times higher than the dark rate)

Table 3. Effect of light on $\mathrm{NO}_{3}{ }^{-}$and $\mathrm{NH}_{4}{ }^{+}$uptake $\left(\mathrm{nmol} \mathrm{cm}{ }^{-2} \mathrm{~h}^{-1}\right.$ ) by Himantothallus grandifolius and Laminaria solidungula Results represent the mean $( \pm 1 \mathrm{SE})$ of 5 or 6 individual plants. Initial substrate concentrations are shown in parentheses

\begin{tabular}{|c|c|c|c|c|}
\hline & \multicolumn{2}{|c|}{ H. grandifolius } & \multicolumn{2}{|c|}{ L. solidungula } \\
\hline & Dark & Light & Dark & Light \\
\hline $\mathrm{NO}_{3}{ }^{-}$ & $\begin{array}{c}-1.15 \pm 0.39 \\
(30 \mu \mathrm{M})\end{array}$ & $\begin{array}{c}8.75 \pm 0.76 \\
(28 \mu \mathrm{M})\end{array}$ & $\begin{array}{c}1.27 \pm 0.58 \\
(6 \mu \mathrm{M})\end{array}$ & $\begin{array}{c}5.21 \pm 0.53 \\
(7 \mu \mathrm{M})\end{array}$ \\
\hline $\mathrm{NH}_{4}^{+}$ & $\begin{array}{l}7.88 \pm 1.30 \\
(10 \mu \mathrm{M})\end{array}$ & $\begin{array}{c}9.83 \pm 1.22 \\
(10 \mu \mathrm{M})\end{array}$ & $\begin{array}{c}3.6 \pm 0.61 \\
(5 \mu \mathrm{M})\end{array}$ & $\begin{array}{c}4.88 \pm 0.32 \\
(4 \mu \mathrm{M})\end{array}$ \\
\hline
\end{tabular}


Table 4. $\mathrm{NO}_{3}{ }^{-}$and $\mathrm{NH}_{4}{ }^{+}$uptake rates ( $\mathrm{nmol} \mathrm{cm}{ }^{-2} \mathrm{~h}^{-1}$ ) of Himantothallus grandifolius and Laminaria solidungula after 1 mo in darkness. Results represent the mean ( $\pm 1 \mathrm{SE}$ ) of 5 individual plants. Numbers in parentheses indicate activity as percentage of control plants $(\mathrm{n}=5)$ grown on a $16 \mathrm{~h}$ light: $8 \mathrm{~h}$ dark cycle at a photon flux density of $50 \mu \mathrm{mol} \mathrm{m} \mathrm{m}^{-2} \mathrm{~s}^{-1}$. All uptake rates were measured in the light at $30 \mu \mathrm{M} \mathrm{NO}_{3}{ }^{-}$or $\mathrm{NH}_{4}{ }^{+}$. "Uptake rates were not measured on these days

\begin{tabular}{|c|c|c|c|c|}
\hline & \multicolumn{2}{|c|}{$\mathrm{NO}_{3}^{-}$} & \multicolumn{2}{|c|}{$\mathrm{NH}_{4}^{+}$} \\
\hline & H. grandifolius & L. solidungula & H. grandifolius & L. solidungula \\
\hline Controls & $7.79 \pm 0.73$ & $5.21 \pm 0.53$ & $3.29 \pm 0.85$ & $4.88 \pm 0.37$ \\
\hline \multicolumn{5}{|l|}{ Dark plants (days in light) } \\
\hline 0 & $\begin{array}{c}-0.34 \pm 0.17 \\
(0)\end{array}$ & $\begin{array}{c}0.43 \pm 0.31 \\
(8)\end{array}$ & $\begin{array}{c}0.66 \pm 0.53 \\
(20)\end{array}$ & $\begin{array}{c}3.60 \pm 0.47 \\
(74)\end{array}$ \\
\hline 2 & $\begin{array}{c}-0.71 \pm 0.49 \\
(0)\end{array}$ & $\begin{array}{c}1.26 \pm 0.22 \\
(24)\end{array}$ & $\begin{array}{c}1.72 \pm 0.47 \\
(52)\end{array}$ & * \\
\hline 7 & $\begin{array}{c}6.43 \pm 0.82 \\
(83)\end{array}$ & $\begin{array}{c}5.95 \pm 0.69 \\
(114)\end{array}$ & $\begin{array}{c}3.77 \pm 0.52 \\
(115)\end{array}$ & * \\
\hline
\end{tabular}

Table 5. Nitrate reductase (NR) activity $\left(\mathrm{nmol} \mathrm{cm} \mathrm{cm}^{-2} \mathrm{~h}^{-1}\right)$ and glutamine synthetase (GS) activity $\left(\mu \mathrm{mol} \mathrm{cm}^{-2} \mathrm{~h}^{-1}\right)$, respectively, in Himantothallus grandifolius and Laminaria solidungula after 1 mo in darkness. Results represent the mean ( \pm 1 SE) of 5 individual plants. Numbers in parentheses indicate activity as a percentage of control plants $(n=5)$ grown on a $16 \mathrm{~h}$ light:8 h dark cycle at a photon flux density of $50 \mu \mathrm{mol} \mathrm{m} \mathrm{m}^{-2} \mathrm{~s}^{-1}$. "Enzyme activities were not measured on these days

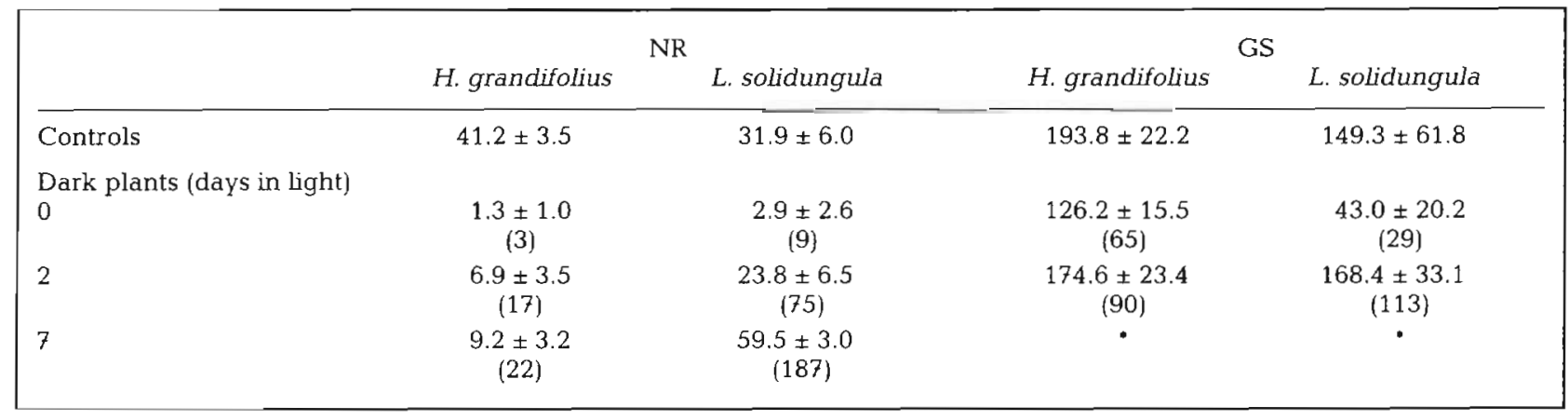

occurred after $8 \mathrm{~h}$ in the light, and activity rapidly declined when darkness resumed. Exposure of both algal species to prolonged darkness caused changes in NR and GS activities (Table 5) similar to changes in $\mathrm{NO}_{3}{ }^{-}$and $\mathrm{NH}_{4}{ }^{+}$uptake, respectively. NR activity was initially very low and significantly different from activity in control plants (ANOVA, $F=23.4, p<0.01$ ), while GS activity immediately after exposure to light was 29 to $65 \%$ of the activity in controls. Unlike $\mathrm{NO}_{3}{ }^{-}$uptake, which showed full recovery after a week of light exposure, NR activity in dark-treated $H$. grandifolius recovered to only $25 \%$ of control activity after $7 \mathrm{~d}$ under a diel light cycle. Dark-treated Laminaria solidungula showed complete recovery of NR activity.

Long-term absence of an external nitrogen source had a stimulatory effect on $\mathrm{N}$-uptake and -assimilation by antarctic plants. Himantothallus grandifolius grown for 1 mo without $\mathrm{NO}_{3}{ }^{-}$demonstrated significantly higher $\mathrm{NO}_{3}{ }^{-}$uptake rates (Student's $t$-test, $\mathrm{p}<0.01$ ) and increased NR activity compared to control plants (Table 6). $\mathrm{N}$-limited Laminaria solidungula, on the other hand, showed similar NR activity to control plants.
Table $6 . \mathrm{NO}_{3}{ }^{-}$uptake rates and nitrate reductase (NR) activity, (nmol cm${ }^{-2} \mathbf{h}^{-1}$ ) of Himantothallus grandifolius and Laminaria solidungula (NR only) after containment in nitrate-free seawater for 1 and $3 \mathrm{mo}$, respectively. Results represent the mean $( \pm 1 \mathrm{SE})$ of 5 individual plants. Numbers in parentheses indicate activity as percentage of control plants ( $n=5$ ) grown in the presence of $240 \mu \mathrm{M} \mathrm{NO}_{3}^{-}$

\begin{tabular}{|lccc|}
\hline & \multicolumn{2}{c}{ H. grandifolius } & $\begin{array}{c}\text { L. solidungula } \\
\text { NR activity }\end{array}$ \\
\hline $\begin{array}{l}\text { Control } \\
\text { plants }\end{array}$ & $7.67 \pm 1.01$ & $28.66 \pm 3.29$ & $64.28 \pm 11.38$ \\
$\begin{array}{l}\text { N-limited } \\
\text { plants }\end{array}$ & $\begin{array}{c}14.35 \pm 1.48 \\
(187)\end{array}$ & $\begin{array}{c}41.6 \pm 6.49 \\
(145)\end{array}$ & $\begin{array}{c}58.56 \pm 6.85 \\
(91)\end{array}$ \\
\hline
\end{tabular}

\section{DISCUSSION}

Nutritional characteristics of seaweeds often show adaptations to local nutrient conditions. Temperate kelps from areas with different seasonal patterns of DIN availability, for example, exhibit variation in nitro- 
gen uptake, activity of enzymes involved in N-assimilation, and nitrogen storage (e.g. Gagné et al. 1982, Espinoza \& Chapman 1983, Wheeler \& Weidner 1983, Davison et al. 1984, Druehl et al. 1989). In the present study, it was expected that polar macroalgae, from similar environments in terms of temperature and light availability, but which have evolved under different nutrient regimes, may have nitrogen uptake and assimilation characteristics suited to their specific environments. Around the Antarctic Peninsula, concentrations of $\mathrm{NO}_{3}{ }^{-}$as high as $30 \mu \mathrm{M}$ are recorded yearround (M. Vernet pers. comm.). $\mathrm{NH}_{4}{ }^{+}$levels are lower than $\mathrm{NO}_{3}{ }^{-}$, generally representing 2 to $10 \%$ of the DIN pool. The variability of $\mathrm{NH}_{4}{ }^{+}$is the result of patches of excretion from krill, birds, and mammals (Olsen 1980). In contrast, arctic seas have much lower levels of both $\mathrm{N}$-forms. Winter $\mathrm{NO}_{3}{ }^{-}$concentrations are approximately 4 to $5 \mu \mathrm{M}$, falling to undetectable levels in the summer (Dunton \& Schell 1986). $\mathrm{NH}_{4}{ }^{+}$concentrations are also low and variable, ranging from 0.03 to $0.4 \mu \mathrm{M}$ (Wheeler \& Kokkinnakis 1990).

Arctic Laminaria solidungula, which is periodically subjected to low DIN concentrations, was expected to have higher affinity and higher maximum uptake rates of $\mathrm{NO}_{3}{ }^{-}$and $\mathrm{NH}_{4}{ }^{+}$than antarctic Himantothallus grandifolius, an alga exposed to constantly high $\mathrm{NO}_{3}^{-}$concentrations. In fact, in a previous study, L. solidungula did not demonstrate saturation kinetics - both $\mathrm{NO}_{3}$ and $\mathrm{NH}_{4}{ }^{+}$uptake rates continued to increase with increasing substrate concentration up to $80 \mu \mathrm{M}$ (Dibble 1994). In the present study, $\mathrm{NO}_{3}^{-}$uptake rates in both the arctic and antarctic species exhibited saturation kinetics, similar to a number of temperate kelp species (Haines \& Wheeler 1978, Harlin \& Craigie 1978, Gerard 1982, Kopczak 1994, Braga \& Yoneshigue-Valentin 1996). The apparent contradiction is probably due to different experimental conditions. In the earlier study, uptake rates measured either in polythene bags or in the laboratory may have been limited by insufficient water motion and, therefore, reflected rates of boundary layer diffusion rather than active uptake (Gerard 1982). The present study found that L. solidungula did indeed have higher maximum $\mathrm{NO}_{3}{ }^{-}$uptake rates than H. grandifolius. However, affinity for $\mathrm{NO}_{3}^{-}$was lower in the arctic plants, and the opposite pattern was seen for $\mathrm{NH}_{4}^{+}$. Obviously, the differences between these species are not simply adaptive responses to low versus high nutrient regimes.

With respect to nutrient uptake kinetics, planktonic microalgae have been categorised as (1) 'affinityadapted' species with low $V_{\text {max }}$, but also low $K_{\text {m }}$ for efficient use of low nutrient concentrations; (2) 'velocity-adapted' species with high $V_{\max }$, high $K_{\mathrm{m}}$, and high maximum growth rates, which utilise nutrient pulses to support periods of rapid growth; and (3) 'storage spe- cialists' with high $V_{\max }$ and high $K_{\mathrm{m}}$, but low maximum growth rates, which utilise pulses for luxury consumption and storage (Sommer 1984). Based on results of the present study, Laminaria solidungula would fall into the 'storage specialist' category. The high $V_{\max }$ for $\mathrm{NO}_{3}{ }^{-}$, coupled with a low maximum growth rate, allows arctic plants to take advantage of seasonally elevated concentrations to accumulate large internal pools of $\mathrm{NO}_{3}{ }^{-}$and organic $\mathrm{N}$-reserves (Henley \& Dunton 1995, Korb \& Gerard 2000). On the basis of $\mathrm{NO}_{3}^{-}$ uptake, Himantothallus grandifolius did not fit well into any of the 3 categories. Although $K_{\mathrm{m}}$ was low in antarctic plants relative to arctic plants, much lower values of $K_{\mathrm{m}}$ have been determined for temperate seaweeds (e.g. Haines \& Wheeler 1978, Harlin \& Craigie 1978, Probyn \& Chapman 1982, Espinoza \& Chapman 1983), and a high-affinity strategy would not be particularly valuable to a species living under constant, high DIN supply. Nor does $H$. grandifolius fit the definitions of 'velocity-adapted' or 'storage specialist' species, since it has a low maximum growth rate and does not accumulate significant internal N-reserves (Korb \& Gerard 2000). Perhaps, the nutritional strategy of this species cannot be defined on the basis of a response to $\mathrm{N}$ supply, because in its natural environment it is limited by low annual irradiance rather than $\mathrm{N}$-availability. In other words, the $\mathrm{N}$-uptake characteristics of $\mathrm{H}$. grandifolius may be adapted to optimise energy consumption rather than $\mathrm{N}$-assimilation.

Preferential use of $\mathrm{NH}_{4}{ }^{+}$over $\mathrm{NO}_{3}{ }^{-}$can be considered as an energy-saving process, because $\mathrm{NO}_{3}{ }^{-}$must be reduced to $\mathrm{NH}_{4}{ }^{+}$prior to incorporation into organic compounds, requiring the equivalent of 8 electrons per $\mathrm{NO}_{3}{ }^{-}$(Syrett 1981). The preferential use of $\mathrm{NH}_{4}{ }^{+}$may, therefore, be viewed as an energetic advantage, especially in polar waters that receive low annual inputs of solar radiation (Dunton \& Dayton 1995). Himantothallus grandifolius had a much higher uptake rate of $\mathrm{NH}_{4}{ }^{+}$ than of $\mathrm{NO}_{3}{ }^{-}$, whether presented with 1 form of DIN or both together (Fig. 2). High $V_{\text {max }}$ values for $\mathrm{NH}_{4}{ }^{+}$would allow the antarctic species to rapidly use pulses of this nutrient when it is available. DIN uptake by $H$. grandifolius may be similar to that of antarctic phytoplankton, which meet their nitrogenous needs largely through $\mathrm{NH}_{4}{ }^{+}$uptake, despite high ambient concentrations of $\mathrm{NO}_{3}^{-}$(Olsen 1980, Glibert et al. 1982, Koike et al. 1986). Similar preference for $\mathrm{NH}_{4}{ }^{+}$was found in the deep-dwelling kelp Laminaria abyssalis (Braga \& Yoneshigue-Valentin 1996) and in the freshwater macroalga Lemanea mamillosa, which grows rapidly in the winter (MacFarlane \& Raven 1990). Arctic Laminaria solidungula, on the other hand, showed similar rates of $\mathrm{NO}_{3}{ }^{-}$and $\mathrm{NH}_{4}{ }^{+}$uptake, whether the $2 \mathrm{DIN}$ forms were presented individually or together. Compared to the antarctic alga, the arctic kelp is subjected 
to lower ambient $\mathrm{NO}_{3}{ }^{-}$concentrations, which peak at 3 to $6 \mu \mathrm{M}$ (Dunton 1985), and probably rarely experiences $\mathrm{NH}_{4}{ }^{+}$concentrations $>1 \mu \mathrm{M}$ (Wheeler \& Kokkinnakis 1990). Minimal interference of uptake between the 2 forms of DIN may enable $L$, solidungula to take advantage of available DIN, regardless of form.

Differences between Himantothallus grandifolius and Laminaria solidungula with respect to effects of darkness on nutrient uptake rates may also reflect a stronger influence of energy limitation in the antarctic species. Assimilation of both $\mathrm{NO}_{3}{ }^{-}$and $\mathrm{NH}_{4}{ }^{+}$is dependent on photosynthesis or on stored photosynthetic products, so that uptake by most algae occurs at a reduced rate in the dark (e.g. DeBoer et al. 1978, Haines \& Wheeler 1978, Syrett 1981, Gerard 1982, Harrison et al. 1986). Although both the antarctic and arctic species demonstrated reduced DIN uptake during shortterm and prolonged periods of darkness, the effect was much greater in $H$. grandifolius, which took up no $\mathrm{NO}_{3}{ }^{-}$and little $\mathrm{NH}_{4}{ }^{+}$in the dark (Tables 3 \& 4). The $\mathrm{N}$-assimilation enzymes similarly exhibited a greater dark-induced reduction and/or a slower recovery of activity in the antarctic alga (Table 5). Since H. grandifolius does not grow during the winter months of darkness (Drew \& Hastings 1992) and does not store internal $N$-reserves, this species has no need to take up DIN in the dark. The arctic kelp, in contrast, completes over $90 \%$ of its annual growth during winter utilising stored carbohydrates (Dunton \& Schell 1986, Dunton 1990). In $L$. solidungula, however, $\mathrm{NO}_{3}{ }^{-}$uptake in the dark was insufficient to meet growth requirements. The average growth rate of this species at $0^{\circ} \mathrm{C}$ is $0.45 \% \mathrm{~d}^{-1}$ (Korb \& Gerard 2000), requiring $0.06 \mu \mathrm{mol} \mathrm{N} \mathrm{g}{ }^{-1}$ fresh $w \mathrm{~h}^{-1}$. $\mathrm{NO}_{3}^{-}$uptake occurred at one-third of this rate in the dark. It is possible that the arctic kelp supports winter growth at least partly on internal organic $\mathrm{N}$-reserves accumulated during periods when both light and DIN are available. Alternatively, under-ice irradiance, although very low (Dunton 1990), may be sufficient to significantly enhance $\mathrm{NO}_{3}{ }^{-}$uptake compared to dark rates and thus support winter growth.

Although reduced rates of $\mathrm{NO}_{3}{ }^{-}$uptake and assimilation may reflect energy conservation, they may also be influenced by $\mathrm{NO}_{3}{ }^{-}$availability. Nitrate reductase is an inducible enzyme, regulated by factors such as nitrate or light (Crawford 1995), whereby activity occurs at constitutive levels in plants grown with no $\mathrm{NO}_{3}{ }^{-}$or light supply and increases with exposure to these factors. The temperate kelps Laminaria saccharina and $L$. digitata showed reduced NR activity under $\mathrm{N}$-limitation, apparently to conserve enzyme protein (Wheeler \& Weidner 1983, Davison et al. 1984). We expected a similar reduction of NR activity in arctic $L$. solidungula under $\mathrm{N}$-limited conditions, and did find a small difference between $\mathrm{N}$-replete and $\mathrm{N}$-limited plants (Table 6). However, the effect was less dramatic than in the temperate species, possibly reflecting the greater ability of the arctic kelp to maintain growth on internal $\mathrm{N}$-reserves for long periods of N-limitation (Henley \& Dunton 1997, Korb \& Gerard 2000). In Himantothallus grandifolius, on the other hand, both NR activity and nitrate uptake rate increased under $\mathrm{N}$-limitation. As this species is never exposed to low nitrate concentrations in nature, it may not have evolved a mechanism to conserve nitrogen by reducing its complement of assimilatory enzymes.

Overall, results of the present study indicated that the large brown algae from the southern and northern polar regions exhibit marked differences in nutritional strategies. The antarctic endemic, although constantly exposed to high nitrate concentrations, preferentially takes up and assimilates $\mathrm{NH}_{4}{ }^{+}$and, hence, is able to take advantage of periodically high concentrations of this nutrient to conserve energy. The arctic endemic utilises the 2 DIN forms more equitably, allowing the plant to minimise the impact of seasonally low concentrations via luxury consumption and storage. Both species conserve energy by reducing rates of $\mathrm{NO}_{3}{ }^{-}$ uptake and assimilation during periods of darkness, but the dark effect is greater in the antarctic alga. Thus, Himantothallus grandifolius exhibits a nutritional strategy that is strongly oriented toward energy conservation, while Laminaria solidungula appears to balance the need to conserve energy with the need to avoid $\mathrm{N}$-limitation in an environment that alternates between low light and low nitrogen availability.

Acknowledgements. We thank Dr Ken Dunton for supplying Laminaria solidungula from the Canadian High Arctic, Dr Jonas Collén for help with collection of Himantothallus grandifolius, and all ASA staff at Palmer Station, Antarctica, especially Randy Sliester, who provided invaluable boat assistance. Thanks are also due to Dave Laby and Bill Grillo for help in maintaining cultures. Funding was provided by the National Science Foundation (OPP 9521496).

\section{LITERATURE CITED}

Amsler CD, Rowley RJ, Laur DR, Quetin LB, Ross RM (1995) Vertical distribution of Antarctic peninsular macroalgae: cover, biomass and species composition. Phycologia 34: $424-430$

Berges JA, Montagnes DJS, Hurd CL, Harrison PJ (1994) Fitting ecological and physiological data to rectangular hyperbolae: a comparison of methods using Monte Carlo simulations. Mar Ecol Prog Ser 114:175-183

Bischoff B, Wiencke C (1993) Temperature requirements for growth and survival of macroalgae from Disko-Island (Greenland). Helgol Meeresunters. 47:167-191

Braga AC, Yoneshigue-Valentin Y (1996) Nitrogen and phosphorous uptake by the Brazilian kelp Laminaria abyssalis (Phaeophyta) in culture. Hyrdrobiologia 326/327:445-450

Chapman ARO, Lindley JE (19809 Seasonal growth of Lami- 
naria solidungula in the Canadian high Arctic in relation to irradiance and dissolved nutrient concentrations. Mar Biol 57:1-5

Crawford NM (1995) Nitrate: nutrient and signal for plant growth. Plant Cell 7:859-868

Davison IR, Stewart WDP (1983) Occurrence and significance of nitrogen transport in the brown alga Laminaria digitata. Mar Biol 77:107-112

Davison IR, Stewart WDP (1984) Studies on nitrate reductase activity in Laminaria digitata (Huds.) Lamour. I. Longitudinal and transverse profiles of nitrate reductase activity within the thallus. J Exp Mar Biol Ecol 74:201-210

Davison IR, Andrews M, Stewart WDP (1984) Regulation of growth in Laminaria digitata: use of in-vitro nitrate reductase activities as an indicator of nitrogen limitation in field populations of Laminaria spp. Mar Biol 84:207-217

DeBoer JA, Guigli HJ, Israel TL, D'Elia CF (1978) Nutritional studies of two red algae. I. Growth rate as a function of nitrogen source and concentration. J Phycol 14:261-266

Dibble JM (1994) Inorganic nitrogen uptake by two kelp species, Laminaria solidungula and Laminaria saccharina, in the Alaskan high Arctic. PhD thesis, University of Texas at Austin

Drew EA, Hastings RM (1992) A year-round ecophysiological study of Himantothallus grandifolius (Desmarestiales, Phaeophyta) at Signy Island, Antarctica. Phycologia 31: 262-277

Druehl LD, Harrison PJ, Lloyd KE, Thompson PA (1989) Phenotypic variation in $\mathrm{N}$ uptake by Laminaria groenlandica Rosenvinge (Laminariales, Phaeophyta). J Exp Mar Biol Ecol 127:155-164

Dunton KH (1984) An annual carbon budget for an arctic kelp community. In: Barnes PW, Schell DM, Reimnitz $E$ (eds) The Alaskan Beaufort Sea: ecosystems and environments. Academic Press, London, p 311-325

Dunton KH (1985) Growth of dark exposed Laminaria saccharina (L.) Lamour. and Laminaria solidungula J. Ag. (Laminariales: Phaeophyta) in the Alaskan Beaufort Sea. J Exp Mar Biol Ecol 94:181-189

Dunton KH (1990) Growth and production in Laminaria solidungula: relation to continuous underwater light levels in the Alaskan high Arctic. Mar Biol 106:297-304

Dunton KH, Dayton PK (1995) The biology of high latitude kelp, In: Skjoldal HR, Hopkins C, Erikstad KE, Leinaas HP (eds) Ecology of fjords and coastal waters. Elsevier Science, Amsterdam, p 499-507

Dunton KH, Schell DM (1986) Seasonal carbon budget and growth of Laminaria solidungula in the Alaskan high Arctic. Mar Ecol Prog Ser 31:57-66

Espinoza J, Chapman ARO (1983) Ecotoypic differentiation of Laminaria longicruris in relation to seawater nitrate concentration. Mar Biol 74:213-218

Gagné JA, Mann KH, Chapman ARO (1982) Seasonal patterns of growth and storage in Laminaria longicruris in relation to differing patterns of availability of nitrogen in the water. Mar Biol 69:91-101

Gao Y, Smith GJ, Alberte RS (1992) Light regulation of nitrate reductase in Ulva fenestrata (Chlorophyceae). I. Influence of light regimes on nitrate reductase activity. Mar Biol 112 : 691-696

Gerard VA (1982) In situ rates of nitrate uptake by giant kelp, Macrocystis pyrifera (L.) C. Agardh: tissue differences, environmental effects, and predictions of nitrogen-limited growth. J Exp Mar Biol Ecol 62:211-224

Glibert PM, Biggs DC, McCarthy JJ (1982) Utilization of ammonium and nitrate during austral summer in the Scotia sea. Deep-Sea Res 29:837-850
Haines KC, Wheeler PA (19789 Ammonium and nitrate uptake by the marine macrophytes Hypnea musciformis (Rhodophyta) and Macrocystis pyrifera (Phaeophyta). J Phycol 14:319-324

Harlin MM, Craigie JS (1978. Nitrate uptake by Laminaria longicruris (Phaeophyceae). J Phycol 14:464-467

Harrison PJ, Druehl LD, Lloyd KE, Thompson PA (1986) Nitrogen uptake kinetics in three year classes of Laminaria groenlandica (Laminariales, Phaeophyta). Mar Biol 93:29-35

Henley WJ, Dunton KH (1995) A seasonal comparison of carbon, nitrogen and pigment content in Laminaria solidungula and Laminaria saccharina (Phaeophyta) in the Alaskan Arctic. J Phycol 31:325-331

Henley WJ, Dunton KH (1997) Effects of nitrogen supply and continuous darkness on growth and photosynthesis of the arctic kelp Laminaria solidungula. Limnol Oceanogr 42: 209-216

Hurd CL, Berges JA, Osborne J, Harrison PJ (1995) An in vitro nitrate reductase assay for marine macroalgae: optimization and characterization of the enzyme for Fucus gardneri (Phaeophyta). J Phycol 31:835-843

Jones MN (1984) Nitrate reduction by shaking with cadmium. Alternative to cadmium columns. Water Res 18:643-646

Koike I, Holm-Hansen O, Briggs DC (1986) Inorganic nitrogen metabolism by antarctic phytoplankton with special reference to nitrogen cycling. Mar Ecol Prog Ser 30: $105-116$

Kopczak CD (1994) Variability of nitrate uptake capacity in Macrocystis pyrifera (Laminariales, Phaeophyta) with nitrate and light availability. J Phycol 30:573-580

Korb RE, Gerard VA (2000) Effects of concurrent low temperature and low nitrogen supply on polar and temperate seaweeds. Mar Ecol Prog Ser 198:73-82

Lopes PF, Oliveira MC, Colepicolo P (1997) Diurnal fluctuation of nitrate reductase activity in the marine red alga Gracilaria tenuistipitata (Rhodophyta). J Phycol 3;225-231

MacFarlane JJ, Raven JA (1990) C, N and P nutrition of Lemanea mamillosa Kutz (Batrachospermales, Rhodophyta) in the Dighty Burn, Angus, Scotland. Plant Cell Environ 13:1-13

Moe RL, Silva PC (1981) Morphology and taxonomy of $\mathrm{Hi}$ mantothallus (including Phaeoglossum and Phyllogigas), an Antarctic member of the Desmarestiales (Phaeophyceae). J Phycol 17:15-29

Newkirk SG (1997) Mechanisms of cold adaptation in arctic kelps. Masters thesis, State University of New York, Stony Brook

Olsen RJ (1980) Nitrate and ammonium uptake in antarctic waters. Limnol Oceanogr 25:1064-1074

Parsons TR, Maita Y, Lalli CM (1984) A manual of chemical and biological methods for seawater analysis. Pergamon Press, Oxford

Probyn TA, Chapman ARO (19829 Nitrogen uptake characteristics of Chordaria flagelliformis (Phaeophyta) in batch mode and continuous mode experiments. Mar Biol 71 : 129-133

Rees TAV, Larson TR, Heldens JWG, Huning FGJ (1995) In situ glutamine synthetase activity in a marine unicellular alga. Development of a sensitive colorimetric assay and the effects of nitrogen status on enzyme activity. Plant Physiol 109:1405-1410

Sellman PV, Delaney AJ, Chamberlain EJ, Dunton KH (1992) Seafloor temperature and conductivity data from Stefansson Sound, Alaska. Cold Regions Sci Tech 31: $491-543$

Sommer U (1984) The paradox of the plankton: fluctuations of 
phosphorous availability maintain diversity of phytoplankton in flow-through cultures. Limnol Oceanogr 29: $633-636$

Syrett PJ (1981) Nitrogen metabolism in microalgae. In: Platt $T$ (ed) Physiological bases of phytoplankton ecology. Journal of the Canadian Fishery and Research Board, Ottawa, p 182-210

Tan IH, Druehl LD (1996) A ribosomal DNA phylogeny supports the close evolutionary relationships among the Sporochnales, Desmarestiales, and Laminariales (Phaeophyceae). J Phycol 32:112-118

Vergara JJ, Berges JA, Falkowski PG (1998) Diel periodicity of nitrate reductase activity and protein levels in the

Editorial responsibility: Otto Kinne (Editor),

Oldendorf/Luhe, Germany marine diatom Thalassiosira weissflogii (Bacillariophyceae). J Phycol 34:952-961

Wheeler PA, Kokkinnakis SA (1990) Ammonium recycling limits nitrate use in the oceanic subarctic Pacific. Limnol Oceanogr 35:1267-1278

Wheeler WN, Weidner M (1983) Effects of external inorganic nitrogen concentration on metabolism, growth and activities of key carbon and nitrogen assimilatory enzymes of Laminaria saccharina (Phaeophyceae) in culture. J Phycol 19:92-96

Wiencke C, tom Dieck I (1989) Temperature requirements for growth and temperature tolerance of macroalgae endemic to the Antarctic region. Mar Ecol Prog Ser 54:189-197

Submitted: June 10, 1999; Accepted: November 5, 1999 Proofs received from author(s): May 3, 2000 